\title{
Perbuatan Melawan Hukum Komisaris terhadap Pemberhentian Sementara Direksi Perseroan Terbatas
}

\author{
Eko Rial Nugroho \\ Alumni Fakultas Hukum Universitas Islam Indonesia \\ Jl. Tamansiswa No. 158 Yogyakarta \\ eko_yayang@yahoo.com
}

\begin{abstract}
The A Limited Liability Company has a company organ which runs the company functions, and the activities of the staff of the organ are not for the interest of themselves but for, on behalf of, and as a form of responsibility of the company as a legal entity. The problems discussed here are: First, is the legal action of the board of commissioners of PT. JOBS DB to temporarily suspend the board of directors of PT. JOBS DB categorized as illegal? Second, what are the legal effects of the action of the board of commissioners of PT. JOBS DB to temporarily suspend the board of directors of PT. JOBS DB which is categorized as illegal? This research aims to find out if the legal action of the board of commissioners of PT. JOBS DB to temporarily suspend the board of directors of PT. JOBS DB is categorized as illegal and the legal effects of the action of the board of commissioners of PT. JOBS DB to temporarily suspend the board of directors of PT. JOBS DB which is categorized as illegal. This research is a normative legal study using qualitative analysis. This research concludes that Sung Samuel Ham Wing as the commissioner of PT. JOBS DB and PT. JOBS DB have violated the provisions regulating the procedures of the termination of the member of the board of directors in both the Laws of Limited Liability Company and the Articles of Establishment of the company, and they have performed the illegal action in accordance to the Article 1365 of Civil Law Code. Therefore, the action of the termination is illegitimate and must never be considered exist.
\end{abstract}

Key words : Company, board of directors, board of commissioners, illegal act

\begin{abstract}
Abstrak
Perseroan Terbatas mempunyai organ perseroan yang menjalankan fungsi perseroan, dan perbuatan para pengurus tersebut bukan untuk dirinya sendiri, tetapi untuk dan atas nama serta tanggung jawab badan hukum perseroan tersebut. Permasalahan yang diteliti, pertama, apakah tindakan hukum Komisaris PT. PT. JOBS DB terhadap pemberhentian sementara Direksi PT. JOBS DB dikategorikan sebagai perbuatan melawan hokum? Kedua, bagaimana akibat hukum atas tindakan Komisaris PT. JOBS DB yang dikategorikan sebagai perbuatan melawan hukum terhadap pemberhentian sementara Direksi PT. JOBS DB? Penelitian ini bertujuan untuk mengetahui apakah tindakan hukum Komisaris PT. PT. JOBS DB terhadap pemberhentian sementara Direksi PT. JOBS DB dikategorikan sebagai perbuatan melawan hukum dan akibat hukum atas tindakan Komisaris PT. JOBS DB yang dikategorikan sebagai perbuatan melawan hukum terhadap pemberhentian sementara Direksi PT. JOBS DB. Penelitian ini merupakan penelitian hukum normatif dengan analisis kualitatif. Penelitian ini menyimpulkan, Sung Samuel Ham Wing selaku Komisaris PT. JOBS DB dan PT. JOBS DB telah melanggar ketentuan-ketentuan yang mengatur tata cara pemberhentian anggota direksi baik di dalam UUPT maupun anggaran dasar perseroan, dan telah melakukan perbuatan melawan hukum sesuai Pasal 1365 KUHPerdata. Oleh karenanya, pemberhentian tersebut tidak sah dan harus dianggap tidak pernah ada.
\end{abstract}

Kata kunci: Perseroan, direksi, komisaris, perbuatan melawan hukum. 


\section{Pendahuluan}

Perseroan Terbatas ${ }^{1}$ sebagai badan hukum, memiliki status, kedudukan dan kewenangan, dapat dipersamakan dengan manusia sehingga disebut artificial person. Perseroan Terbatas (PT) merupakan subjek hukum yang menyandang hak dan/ atau kewajiban yang diakui oleh hukum. PT sebagai subjek hukum dapat melakukan hubungan hukum melalui orang-orang yang menjadi pengurus badan hukum tersebut, dan perbuatan para pengurus tersebut bukan untuk dirinya sendiri, tetapi untuk dan atas nama serta tanggung jawab badan hukum. ${ }^{2}$

Undang-Undang Perseroan Terbatas (UUPT) mengharuskan PT untuk memiliki 3 (tiga) organ, yaitu Rapat Umum Pemegang Saham (RUPS), Direksi dan Dewan Komisaris. $^{3}$

RUPS adalah organ perseroan yang memegang kekuasaan tertinggi dalam perseroan dan memegang segala wewenang yang tidak diserahkan kepada direksi dan dewan komisaris dalam batas yang ditentukan dalam undang-undang ini dan atau anggaran dasar, serta mempunyai kewenangan mengangkat dan memberhentikan direksi dan dewan komisaris.

Direksi, diangkat RUPS, berwenang dan bertanggung jawab atas pengurusan perseroan untuk kepentingan perseroan, sesuai maksud dan tujuan perseroan serta mewakili perseroan, baik di dalam maupun di luar pengadilan sesuai dengan ketentuan anggaran dasar. Anggota direksi dapat diberhentikan sewaktu-waktu berdasarkan keputusan RUPS, dengan alasan anggota direksi melakukan tindakan yang merugikan perseroan atau karena alasan lain yang dinilai tepat oleh RUPS 4

Dalam menjalankan perseroan, direksi diawasi dewan komisari ${ }^{5}$, yang bertugas melakukan pengawasan secara umum dan/atau khusus sesuai dengan anggaran dasar serta memberikan nasihat kepada direksi. Dewan komisaris juga melakukan pengawasan atas kebijakan pengurusan, jalannya pengurusan pada umumnya, baik mengenai perseroan maupun usaha perseroan agar perusahaan tidak melakukan perbuatan melanggar hukum yang merugikan perseroan, shareholders dan stakeholders, UUPT)

${ }^{1}$ Pasal 1 angka 1 Undang-Undang Nomor 40 Tahun 2007 tentang Perseroan Terbatas (selanjutnya disebut

${ }^{2}$ Ridwan Khairandy, Perseroan Terbatas; Doktrin, Peraturan Perundang-undangan, dan Yurisprudensi, Penerbit Kreasi Total Media, Yogyakarta, Cetakan Kedua (revisi), 2009, hlm. 177, yang mengutip Ali Ridho, Badan Hukum dan Kedudukan Badan Hukum Perseroan, Perkumpulan, Koperasi, Yayasan, Wakaf, Alumni, Bandung, 1986, hlm. 17

${ }^{3}$ Ibid., hlm. 178

${ }^{4}$ Ibid., hlm. 218-219., lihat juga Pasal 105 UUPT dan Penjelasan Pasal 105 ayat (1) UUPT.

${ }^{5}$ Pasal 1 angka 6 UUPT 
serta berwenang melakukan pemberhentian sementara terhadap direksi, berdasarkan pemberhentian anggota direksi oleh RUPS membutuhkan waktu untuk pelaksanaannya, sedangkan kepentingan perseroan tidak dapat ditunda. ${ }^{6}$

Ada kasus menarik antara PT. JOBS DB7 Indonesia dengan Eddy Santoso Tjahja. Kasus ini di awali pada 22 April 2008 Sung Samuel Ham Wing selaku Komisaris PT. JOBS DB memberhentikan Eddy Santoso Tjahja dari kedudukannya sebagai direktur pengelola PT. JOBS DB Indonesia dengan cara mengirimkan surat elektronik, dengan alasan, yaitu perjanjian kerja waktu tertentu, rencana merger Jobs DB Hong Kong dengan PT Auditsi, investasi di PT 88DB.com, dan pemindahan aset keuangan PT. JOBS DB Indonesia ke Hongkong.

Pada 24 April 2008 Eddy Santoso Tjahja menerima surat elektronik kembali, yang mengacu surat elektronik pertama, yang berisi memberikan penghargaan atas jasa-jasa Eddy Santoso Tjahja terhadap PT. JOBS DB sebagai Direktur Pengelola dengan memberikan paket kompensasi sebesar 25,3 (dua puluh lima 3/10) bulan gaji ditambah 2 (dua) bulan.

Dalam waktu 16 (enam belas) hari terhitung sejak 22 April s.d. 8 Mei 2008 dilakukan pemanggilan Rapat Umum Pemegang Saham Luar Biasa (RUPSLB), di mana Sung Samuel Ham Wing selaku Komisaris PT. JOBS DB dan PT.JOBS DB mengirim 2 (dua) undangan RUPSLB kepada Eddy Santoso Tjahja untuk hadir dalam RUPSLB pada 26 Mei 2008 dengan agenda utama pemberhentian Eddy Santoso Tjahja selaku Direksi Perseroan secara permanen (tetap).

Dari fakta-fakta hukum tersebut, Eddy Santoso Tjahja mengalami kerugian, selain tidak dapat melakukan aktivitasnya sebagai Direktur Pengelola Operasional PT. JOBS DB, dan tidak menerima honorarium dan tunjangan-tunjangan dan hakhak lainnya.

\footnotetext{
${ }^{6}$ Ridwan Khairandy, Op.Cit., hlm. 219

${ }^{7}$ PT. JOBS DB Indonesia merupakan sebuah Perusahaan Penanaman Modal Asing, suatu badan hukum Perseroan Terbatas yang berkedudukan di Jakarta, beralamat kantor di 5th Floor Wisma 77, Jl. Letjen. S. Parman Kav. 77, Slipi, Jakarta 11410 Indonesia, yang didirikan berdasarkan Akta Pendirian atau Anggaran Dasar PT. JOBS DB Indonesia Nomor 1 tanggal 6 Desember 1999 yang dibuat dan ditandatangani di hadapan Anastasia Zaidulfar, SH, dan berdasarkan Surat Persetujuan Menteri/Kepala Badan Koordinasi Penanaman Modal (BKPM) atas nama Presiden Republik Indonesia No. 658/I/PMA/1999, 22 September 1999, Akta Pendirian/Anggaran Dasar mana telah mengalami beberapa kali perubahan.
} 


\section{Rumusan Masalah}

Adapun permasalahan yang diteliti: Pertama, apakah tindakan hukum Komisaris PT. PT. JOBS DB terhadap pemberhentian sementara Direksi PT. JOBS DB dikategorikan sebagai perbuatan melawan hukum; Kedua, bagaimana akibat hukum atas tindakan Komisaris PT. JOBS DB yang dikategorikan sebagai perbuatan melawan hukum terhadap pemberhentian sementara Direksi PT. JOBS DB?

\section{Tujuan Penelitian}

Penelitian ini bertujuan untuk mengetahui apakah tindakan hukum Komisaris PT. PT. JOBS DB terhadap pemberhentian sementara Direksi PT. PT. JOBS DB sebagai perbuatan melawan hukum dan akibat hukum Komisaris PT. JOBS DB yang dikategorikan sebagai perbuatan melawan hukum terhadap pemberhentian sementara Direksi PT. JOBS DB.

\section{Metode Penelitian}

Penelitian ini merupakan penelitian hukum normatif, yaitu penelitian yang dilakukan dengan mendasarkan pada data kepustakaan sebagai data utamanya yang merupakan data sekunder dan berupa bahan-bahan hukum. Bahan hukum yang digunakan antara lain: Kitab Undang-undang Hukum Perdata, Undang-undang Nomor 40 Tahun 2007 tentang Perseroan Terbatas, Putusan Pengadilan Negeri Jakarta Barat Nomor Perkara 451/Pdt.G/2008/PN.Jkt.Bar.

Bahan-bahan hukum yang telah dikelompokkan dan diklasifikasikan, selanjutnya dianalisis dengan menggunakan analisis kualitatif. Dengan analisis kualitatif tersebut, langkah yang ditempuh didasarkan logika yuridis, sehingga permasalahannya dijelaskan dalam penulisan tesis ini.

\section{Hasil Penelitian dan Pembahasan}

Dalam kasus PT. JOBS DB dengan Eddy Santoso Tjahja, Sung Samuel Ham Wing selaku Komisaris PT. JOBS DB telah memberhentikan Eddy Santoso Tjahja secara tetap dan permanen dari kedudukannya sebagai direktur. 
Sebenarnya Sung Samuel Ham Wing selaku Komisaris PT. JOBS DB dapat memberhentikan sementara anggota direksi ${ }^{8}$. Selaku dewan komisaris, mempunyai pilihan melaksanakan atau tidak melaksanakan hak atau kewenangan tersebut yang diikuti dengan kewajiban menyebutkan alasan pemberhentiannya. Namun, Sung Samuel Ham Wing selaku Komisaris PT. JOBS DB tidak menggunakan mekanisme pemberhentian sementara, melainkan langsung menggunakan mekanisme pemberhentian secara tetap terhadap Eddy Santoso Tjahja tanpa melalui RUPS.

Fakta hukumnya, adanya surat elektronik tertanggal 22 dan 24 April 2008 yang intinya berisi pemberhentian Eddy Santoso Tjahja sebagai Direksi PT. JOBS DB secara tetap atau permanen dan memutuskan memberikan penghargaan atas jasa-jasa Eddy Santoso Tjahja terhadap PT. JOBS DB sebagai Direktur Pengelola dengan memberikan paket kompensasi sebesar 25,3 (dua puluh lima 3/10) bulan gaji ditambah 2 (dua) bulan.

Ini bentuk penyimpangan Sung Samuel Ham Wing selaku Komisaris PT. JOBS DB yang telah memberhentikan secara tetap atau permanen terhadap Eddy Santoso Tjahja sebagai direktur di PT. JOBS. DB. Pasal 106 UUPT hanya memberi hak dan kewenangan kepada dewan komisaris sebatas memberhentikan sementara, dan tidak untuk memberhentikan anggota direksi secara tetap atau permanen. Kewenangan sepenuhnya untuk memberhentikan anggota direksi ada pada pemegang saham yang diimplementasikan dalam RUPS.

Sehingga Sung Samuel Ham Wing selaku Komisaris PT. JOBS DB tidak mempunyai kewenangan penuh atas pemberhentian secara tetap Eddy Santoso Tjahja sebagai direktur, karena kewenangan untuk memutuskan dan menetapkan pemberhentian secara tetap ada pada RUPS, bukan komisaris. Selain itu, apabila dewan komisaris akan memberhentikan sementara anggota direksi, maka diikuti dengan kewajiban untuk menyebutkan alasan pemberhentian sementara tersebut, mengingat pemberhentian sementara terhadap anggota direksi tanpa disertai dengan menyebutkan alasannya pada dasarnya adalah tidak sah ${ }^{9}$.

Dalam hal, alasan pemberhentian ${ }^{10}$ Eddy Santoso Tjahja sebagai direksi PT. JOBS DB, alasan-alasan pemberhentian yang disampaikan, semuanya tidak beralasan dan tidak memenuhi kualifikasi alasan-alasan dalam UUPT. Alasan-alasan

\footnotetext{
${ }^{8}$ Pasal 106 ayat (1) UUPT

${ }^{9}$ Pasal 106 ayat (1) UUPT

${ }^{10}$ Adanya perbedaan pendapat tentang perjanjian kerja waktu tertentu, rencana merger JOBS DB Hongkong dengan PT Auditsi, investasi di PT 88DB.com, dan pemindahan aset keuangan PT. JOBS DB Indonesia ke Hongkong
} 
pemberhentian anggota direksi seharusnya menurut penjelasan Pasal 105 ayat (1) UUPT, disamping alasan pemberhentian yang dianggap umum, juga anggota direksi yang bersangkutan harus terbukti melakukan kesalahan dalam bentuk penyalahgunaan kepercayaan atau menyalahgunakan jabatan. Di dalam Penjelasan Pasal 105 ayat (1) UUPT alasan-alasan pemberhentian anggota direksi disebutkan, pertama, anggota direksi melakukan tindakan yang merugikan perseroan, atau, kedua, karena alasan lain yang dinilai tepat oleh RUPS.

Alasan pertama, indikasi secara konkret dan objektif, misalnya ${ }^{11}$, 1) anggota direksi melakukan kesalahan, karena melanggar kewajiban itikad baik dengan cara menyalahgunakan kedudukan yang mendatangkan kerugian. 2) tidak tekun, tidak cakap serta tidak mampu menjalankan pengurusan perseroan yang mengakibatkan perseroan mengalami kerugian. 3) menggunakan uang atau harta kekayaan perseroan untuk kepentingan diri pribadi anggota direksi yang bersangkutan. 4) mengambil atau menggelapkan sebagian keuntungan perusahaan untuk kepentingan pribadi. 5) melakukan tindakan pengurusan perseroan untuk tujuan yang tidak wajar, dan 6) melanggar ketentuan peraturan perundang-undangan yang berlaku, sehingga dikategorikan melanggar statuta duty yang wajib dipatuhinya.

Selain itu juga pelanggaran kewajiban baik kewajiban administratif maupun yuridis yang dikonstruksikan sebagai alasan tidak memenuhi syarat lagi sebagai anggota direksi. Contohnya anggota direksi tidak melaksanakan kewajiban administratif membuat daftar pemegang saham dan daftar khusus. Selain itu juga, tindakan memberikan kuasa umum kepada seseorang untuk mengurus dan mewakili perseroan, padahal yang boleh diberikan direksi kepada seorang kuasa, hanya kuasa khusus untuk melakukan perbuatan hukum tertentu ${ }^{12}$ atau mengajukan permohonan mempailitkan perseroan secara voluntary petition tanpa terlebih dahulu mendapat persetujuan RUPS. ${ }^{13}$

Alasan kedua yang menyebutkan karena alasan lain yang dinilai tepat oleh RUPS, di mana alasan ini ditinjau dari ilmu hukum merupakan perumusan yang mengandung arti luas tanpa batas dan sekaligus dikategorikan perumusan yang kabur, serta memberikan keleluasaan kepada RUPS untuk menentukan dan menilai alasan pemberhentian yang dianggapnya tepat. Hal ini seolah-olah undang-undang

\footnotetext{
${ }^{11}$ M. Yahya Harahap, Hukum Perseroan Terbatas, Penerbit Sinar Grafika, Cetakan Pertama, Jakarta, Juni 2009, hlm. 418-419

${ }^{12}$ Pasal 103 UUPT, lihat juga M. Yahya Harahap, Ibid., hlm. 419

${ }^{13}$ Pasal 104 ayat (1) UUPT, lihat juga M. Yahya Harahap, Op.Cit., hlm. 419
} 
memberi dorongan kepada RUPS untuk memberhentikan direksi berdasarkan alasan yang abstrak dan subjektif, karena hukum sendiri yang memberi kewenangan RUPS untuk mempergunakan alasan pemberhentian anggota direksi yang dinilai RUPS tepat.

Dari berbagai alasan pemberhentian tersebut, Eddy Santoso Tjahja sebagai direksi tidak melakukan kegiatan yang merugikan perseroan dengan segala indikator-indikatornya. Bahkan Eddy Santoso Tjahja selaku direktur pengelola telah melaksanakan tugas dan kewajibannya sesuai anggaran dasar perseroan sehingga PT. JOBS DB dikenal dan terbesar di bidangnya di Indonesia. Tanggung jawab Eddy Santoso Tjahja telah diterima PT. JOBS DB dan diketahui Sung Samuel Ham Wing selaku Komisaris yang dituangkan dalam akta pernyataan keputusan rapat PT. JOBS DB Indonesia nomor 72 tanggal 28 Desember 2007 yang berisi diantaranya, pertama, menyetujui menerima dan mengesahkan laporan keuangan perseroan (PT. JOBS DB) untuk tahun buku 2007 dan dengan ini memberikan kebebasan pertanggungjawaban dari pengurus perseroan untuk laporan keuangan perseroan untuk tahun buku 2007. Kedua, menyetujui pembagian deviden senilai Rp. 1.836.000.000,00 (satu milyar delapan ratus tiga puluh enam juta rupiah) kepada pemegang saham JOBS DB INC. senilai Rp. 1.652.400.000,00 (satu milyar delapan ratus ribu rupiah) dan PT. Metro Pacific, senilai Rp. 183.600.000,00 (seratus delapan puluh tiga juta enam ratus ribu rupiah). Jumlah dan pembagian dividen tersebut di atas adalah hasil dari kerja keras Eddy Santoso Tjahja untuk memajukan kegiatan usaha PT. JOBS DB, dan ketiga, seluruh tanggung jawab Eddy Santoso Tjahja untuk tahun buku perseroan hingga tahun 2007 telah diberikan pembebasan dan pelunasan (acquit at decharge) sehingga tidak ada dasar alasan yang logis dan kuat Eddy Santoso Tjahja tidak diberi pembebasan dan pelunasan dalam RUPSLB.

Alasan pemberhentian Eddy Santoso Tjahja jika mengacu penjelasan Pasal 105 ayat (1) UUPT yang kedua yaitu karena alasan lain yang tepat oleh RUPS, meskipun karena alasan lain yang tepat oleh RUPS sangat sumir, dan tidak beralasan, namun RUPS tidak pernah diselenggarakan untuk memberhentikan secara tetap atau permanen terhadap Eddy Santoso Tjahja. Sehingga alasan pemberhentian yang dibuat Sung Samuel Ham Wing selaku Komisaris PT. JOBS DB dan PT. JOBS DB dalam memberhentikan Eddy Santoso Tjahja selaku direktur pelaksana PT. JOBS DB tidak didasarkan atas kesepakatan dalam forum RUPS.

Eddy Santoso Tjahja telah menerima undangan untuk menghadiri RUPSLB Perseroan pada 26 Mei 2008, dengan agenda utama pemberhentian Eddy Santoso 
Tjahja selaku direksi perseroan secara permanen. ${ }^{14}$ Penyelenggaraan RUPSLB pada 26 Mei 2008 oleh Sung Samuel Ham Wing selaku Komisaris PT. JOBS DB dan PT. JOBS DB tersebut telah melebihi waktu 30 (tiga puluh) hari, di mana apabila Sung Samuel Ham Wing selaku Komisaris PT. JOBS dan PT. JOBS DB menganggap surat elektronik tertanggal 22 April 2008 sebagai surat pemberhentian sementara, maka terjadi rentang waktu 34 (tiga puluh empat) hingga diadakannya RUPSLB pada 26 Mei 2008.

Hal ini bertentangan dengan Pasal 106 ayat (4) UUPT, di mana dalam jangka waktu 30 (tiga puluh) hari setelah tanggal pemberhentian sementara, harus dilaksanakan RUPS. Pelanggaran atas tidak diselenggarakannya RUPS dalam jangka waktu 30 (tiga puluh) hari setelah tanggal pemberhentian sementara, sesuai Pasal 106 ayat (8) UUPT, apabila RUPS tidak diselenggarakan dalam jangka waktu paling lambat 30 (tiga puluh) hari dari tanggal pemberhentian, mempunyai akibat hukum pemberhentian sementara menjadi batal. Oleh karenanya secara hukum RUPSLB perseroan pada 26 Mei 2008 adalah tidak sah dan melanggar hukum.

Apalagi di dalam RUPSLB tersebut Sung Samuel Ham Wing selaku Komisaris PT. JOBS tidak memberikan kesempatan kepada Eddy Santoso Tjahja untuk membela diri. Fakta hukum ini membuktikan, Sung Samuel Ham Wing dan PT. JOBS DB telah melanggar ketentuan Pasal 106 ayat (5) UUPT. Seharusnya RUPSLB wajib memberikan kesempatan kepada anggota direksi yang bersangkutan untuk membela diri di forum RUPSLB, mengingat pembelaan diri dalam RUPS bersifat imperatif.

Selain itu, apabila terjadi pemberhentian sementara Eddy Santoso Tjahja oleh Sung Samuel Ham Wing selaku komisaris PT. JOBS DB, maka pemberhentian sementara terhadap anggota direksi oleh dewan komisaris harus diberitahukan secara tertulis kepada anggota direksi yang bersangkutan. Oleh karena itu pemberitahuan pemberhentian sementara tersebut tidak disampaikan secara lisan serta tidak dapat dilakukan melalui media surat elektronik. Sehingga "pemberhentian sementara" oleh Sung Samuel Ham Wing tidak dibenarkan karena menggunakan surat elektronik. ${ }^{15}$

\footnotetext{
${ }^{14}$ Isi naskah aslinya adalah sebagai berikut: "To permanently terminate Mr. Eddy Santoso Tjabja as Director of the Company without releasing him from any liabilities during his incumbency period as of the date of the EGMS (with no acquit at decharge);...etc. Terjemahan resminya adalah, Memberhentikan secara tetap Tuan Eddy Santoso Tjahja selaku Direktur Perseroan tanpa membebaskannya dari kewajiban-kewajiban selama masa jabatannya hingga tanggal Rapat Umum pemegang Saham Luar Biasa (dengan tanpa acquit at decharge)...dst.

${ }^{15}$ Pasal 106 ayat (2) UUPT
} 
Sung Samuel Ham Wing selaku Komisaris PT. JOBS DB dan PT. JOBS DB menggunakan mekanisme pemberhentian secara tetap atau permanen terhadap Eddy Santoso Tjahja tanpa melalui RUPS. Ini merupakan bentuk pelanggaran terhadap ketentuan UUPT, karena pemberhentian anggota direksi dapat dilakukan sewaktu-waktu berdasarkan keputusan RUPS ${ }^{16}$. Prinsip Pasal 105 ayat (1) UUPT ini sejalan dengan Pasal 97 ayat (1) UUPT bahwa yang mengangkat anggota direksi adalah RUPS, sehingga RUPS dapat memberhentikan sewaktu-waktu anggota direksi.

Pemberhentian anggota direksi dilakukan oleh pemegang saham melalui RUPS, ditempuh 2 (dua) forum, pertama, pemberhentian anggota direksi oleh pemegang saham dalam forum RUPS secara fisik. Hal ini dituangkan dalam keputusan RUPS melalui tata cara 1). Pemegang saham mengadakan RUPS dengan agenda acara pemberhentian anggota direksi, dengan pemanggilan pemegang saham untuk RUPS sesuai dengan syarat dan tata cara yang ditentukan dalam Pasal 82 UUPT. Dengan berdasarkan pemanggilan tersebut, dilangsungkan RUPS secara fisik sesuai dengan ketentuan Pasal 84 dan 85, di mana RUPS tersebut harus RUPSLB yang khusus membicarakan agenda acara pemberhentian anggota direksi yang bersangkutan. 2). Keputusan pemberhentian disertai dengan alasan. 3). RUPS wajib memberi kesempatan kepada anggota direksi membela diri, di mana pembelaan diri ini bersifat imperatif atau hukum memaksa kecuali anggota direksi yang diberhentikan tersebut menyatakan tidak keberatan atas pemberhentiannya, sehingga pembelaan diri tidak diperlukan ${ }^{17}$. Pembelaan diri anggota direksi yang akan diberhentikan sebaiknya dibuat secara tertulis agar tidak terjadi silang pendapat atau pengingkaran. ${ }^{18}$ Kedua, pemberhentian anggota direksi berdasarkan keputusan di luar forum RUPS secara fisik (usul keputusan yang diedarkan) dengan cara 1). mengirimkan secara tertulis usul yang akan diputuskan kepada semua pemegang saham. 2). usul tersebut disetujui secara tertulis oleh seluruh pemegang saham, dan 3). semua pemegang saham menandatangani usul yang telah disetujui.

Apabila sistem ini yang digunakan maka harus memperhatikan Pasal 105 ayat (3), di mana memberitahukan terlebih dahulu kepada anggota direksi yang bersangkutan tentang rencana pemberhentian dirinya melalui sistem keputusan di

\footnotetext{
${ }^{16}$ Pasal 105 ayat (1) UUPT

${ }^{17}$ Pasal 105 ayat (4) UUPT

${ }^{18}$ M. Yahya Harahap, Op.Cit., hlm. 422, yang dikutip oleh Majelis Hakim Pemeriksa perkara 451/Pdt.G/2008/ PN.JKT.BAR., hlm.56
} 
luar forum RUPS secara fisik dan pemberitahuan harus secara tertulis kepada anggota direksi yang bersangkutan. Selanjutnya memberikan kesempatan kepada anggota direksi yang bersangkutan menyampaikan pembelaaan diri. ${ }^{19}$

Dengan demikian Sung Samuel Ham Wing selaku Komisaris PT. JOBS DB dan PT. JOBS DB dalam memberhentikan Eddy Santoso Tjahja secara tetap atau permanen telah melanggar Pasal 105 UUPT, karena mekanisme pemberhentian Eddy Santoso Tjahja tidak berdasarkan keputusan RUPS, sedangkan yang mempunyai kewenangan memberhentikan secara definitif dan permanen adalah pemegang saham dalam kedudukan dan kapasitas sebagai pemilik perseroan yang diimplementasikan dalam organ RUPS. Forum RUPS sendiri, dalam hal untuk memberhentikan secara tetap atau permanen terhadap diri Eddy Santoso Tjahja juga tidak pernah diselenggarakan baik di dalam forum RUPS maupun di luar RUPS, apalagi memberikan kesempatan kepada Eddy Santoso Tjahja untuk membela diri di dalam forum RUPS, karena forum RUPS sendiri tidak pernah ada.

Apabila Sung Samuel Ham Wing selaku Komisaris PT. JOBS DB menggunakan argumen Pasal 105 ayat (3) UUPT, maka seharusnya Eddy Santoso Tjahja selain diberitahu terlebih dahulu tentang rencana pemberhentian juga diberikan kesempatan untuk membela diri sebelum diambil keputusan pemberhentian.

Hal demikian tidak dilakukan oleh pihak Sung Samuel Ham Wing selaku Komisaris PT. JOBS DB dan Pihak PT. JOBS DB, meskipun dalam surat elektronik pertama, pada 22 April 2008 berjudul "pemberitahuan pemutusan hubungan kerja", namun isi surat elektronik tersebut pemberhentian secara tetap atau permanen terhadap diri Eddy Santoso Tjahja sebagai direktur, yang disusul surat elektronik kedua, pada 24 April 2008 yang memutuskan memberikan penghargaan atas jasajasa Eddy Santoso Tjahja terhadap PT. JOBS DB sebagai managing director sebesar 25,3 (dua puluh lima 3/10) bulan gaji ditambah 2 (dua) bulan.

Sung Samuel Ham Wing selaku Komisaris PT. JOBS DB dan PT. JOBS DB juga telah melanggar Pasal 105 ayat (3) UUPT, di mana anggota direksi (dalam hal ini Eddy santoso Tjahja) yang akan diberhentikan melalui sistem keputusan di luar forum RUPS secara fisik, tidak diberikan kesempatan menyampaikan pembelaaan diri secara tertulis. Penjelasan Pasal 105 ayat (3) UUPT menyatakan bahwa anggota direksi diberi kesempatan membela diri secara tertulis, mengingat hal ini bersifat

${ }^{19}$ Dalam Penjelasan Pasal 105 ayat (3) UUPT pembelaan diri ini dilakukan secara tertulis dan bersifat imperatif kecuali anggota direksi yang bersangkutan tidak keberatan atas pemberhentiannya tersebut. 
imperatif (memaksa) kecuali anggota direksi yang bersangkutan tidak keberatan atas pemberhentiannya tersebut.

Pelanggaran Sung Samuel Ham Wing selaku Komisaris PT. JOBS dan PT. JOBS DB lainnya, di mana pada Pasal 14 ayat (4) dan (5) anggaran dasar perseroan menyebutkan bahwa pemberhentian direktur secara tetap melalui mekanisme atau prosedur pemberhentian sementara, ${ }^{20}$ mengingat faktanya Eddy Santoso Tjahja tidak pernah diberhentikan sementara oleh Sung Samuel Ham Wing selaku Komisaris PT. JOBS DB.

Dalam mekanisme pemanggilan RUPSLB untuk pemberhentian anggota direksi secara tetap atau permanen dengan jangka waktu 30 (tiga puluh) hari sebagaimana ketentuan Pasal 14 ayat (5) anggaran dasar perseroan jo. Pasal 106 ayat (4) UUPT hanya dapat terjadi atas dasar adanya surat pemberhentian sementara. Namun fakta hukumnya surat pemberhentian sementara atas diri Eddy Santoso Tjahja tidak pernah ada. Sehingga mekanisme pemanggilan RUPSLB dalam rangka persetujuan pemberhentian anggota direksi secara tetap atau permanen tidak memenuhi persyaratan dalam anggaran dasar perseroan dan atau UUPT.

Berdasarkan hal-hal tersebut di atas, Eddy Santoso Tjahja mengalami kerugian yang berasal dari perbuatan Sung Samuel Ham Wing selaku Komisaris PT. JOBS dan PT. JOBS DB yang semena-mena dan melawan hukum memberhentikan Eddy Santoso Tjahja dari kedudukannya selaku direktur PT. JOBS DB dengan melanggar ketentuan peraturan perundang-undangan yang berlaku, baik UUPT maupun anggaran dasar perseroan.

Untuk itu, Eddy Santoso Tjahja dapat mengajukan gugatan perbuatan melawan hukum yang timbul dari tindakan perbuatan melawan hukum yang dilakukan Sung Samuel Ham Wing selaku Komisaris PT. JOBS dan PT. JOBS DB, baik secara pribadi maupun terhadap perseroan. Gugatan perbuatan melawan hukum ditujukan kepada Sung Samuel Ham Wing selaku Komisaris PT. JOBS DB, karena yang bersangkutan melakukan tindakan yang berkaitan dengan proses pemberhentian Eddy Santoso Tjahja sebagai Direktur PT. JOBS DB dalam kapasitasnya selaku Komisaris PT. JOBS DB yang bertindak untuk dan atas nama PT. JOBS DB.

Gugatan perbuatan melawan hukum ini dapat ditujukan kepada pribadi Sung Samuel Ham Wing, meskipun yang bersangkutan bertindak selaku Komisaris PT.

${ }^{20}$ Gugatan Eddy Santoso Tjahja terhadap Sung Samuel Ham Wing selaku Komisaris PT. JOBS DB, PT. JOBS DB, dan Elvie Sahdalena, hlm. 6-7., lihat juga Putusan Pengadilan Negeri Jakarta Barat dengan nomor perkara 451/ Pdt.G/2008/PN.JKT.BAR. 
JOBS DB. Sung Samuel Ham Wing telah melakukan kesalahan atau kelalaian dalam memberhentikan Eddy Santoso Tjahja selaku direktur pelaksana di PT. JOBS DB yang tidak sesuai dengan ketentuan peraturan perundang-undangan yang berlaku baik UUPT maupun anggaran dasar perseroan dan menimbulkan kerugian perseroan. Sehingga perbuatan hukum yang dilakukan oleh Sung Samuel Ham Wing menjadi tanggung jawab pribadinya bukan menjadi tanggung jawab perseroan.

Hal ini ditegaskan dalam Pasal 114 ayat (3) UUPT menyatakan bahwa: “Setiap anggota dewan komisaris bertanggung jawab secara pribadi atas kesalahan/kelalaian menjalankan tugas apabila kesalahan/kelalaiannya itu menimbulkan kerugian."

Konstruksi tanggung jawab pribadi anggota dewan komisaris yang salah dan lalai melaksanakan tugas ${ }^{21}$ menyatakan bahwa, pertama, setiap anggota dewan komisaris ikut bertanggungjawab secara pribadi atas kerugian perseroan. Kedua, tanggung jawab pribadi melekat pada diri anggota dewan komisaris apabila ia bersalah atau lalai menjalankan tugas pengawasan atau pemberian nasihat. Ketiga, meskipun kerugian itu timbul dari pengurusan direksi, anggota dewan komisaris tetap bertanggung jawab secara pribadi apabila dalam pengawasan pelaksanaan pengurusan direksi itu terdapat unsur kesalahan atau kelalaian dewan komisaris. Keempat, luasnya tanggung jawab pribadi anggota dewan komisaris, sebatas kesalahan atau kelalaiannya, dan kelima, apabila anggota dewan komisaris terdiri atas 2 (dua) atau lebih, tanggung jawab pribadi itu, bersifat tanggung jawab secara tanggung renteng bagi setiap anggota dewan komisaris. Dengan demikian tindakan Sung Samuel Ham Wing bertanggungjawab secara pribadi atas kesalahan/kelalaian dalam menjalankan tugasnya.

PT. JOBS DB juga dapat dimintakan pertanggungjawabannya atas perbuatan melawan hukum terhadap pemberhentian Eddy Santoso Tjahja. Perseroan sebagai badan hukum yang memiliki personalitas hukum sebagai subjek hukum. Seorang direktur perseroan tidak dapat digugat secara perdata atas perjanjian yang dibuat untuk dan atas nama perseroan, sehingga yang dapat digugat adalah perseroan yang bersangkutan, karena perseroan adalah badan hukum tersendiri, yang merupakan subjek hukum yang terlepas dari pengurusnya (direksi). ${ }^{22}$

Oleh karena itu, apabila tindakan perseroan dilakukan oleh orang yang mempunyai wewenang dan kapasitas untuk bertindak melakukan perbuatan hukum

\footnotetext{
${ }^{21}$ M. Yahya Harahap, Op.Cit., hlm. 460-461

${ }^{22}$ Putusan MA No. 047 K/Pdt/1988, tanggal 20 Januari 1993, dalam Gautama, Himpunan Yurisprudensi Indonesia yang penting untuk praktik (Hand Mark), Jilid 14, Citra Aditya Bakti, 1995, hlm. 347
} 
sesuai dengan fungsi yang diberikan kepadanya dan ternyata hal tersebut "salah", karena melanggar hukum atau hak orang lain, maka perseroan dianggap memenuhi unsur "kesalahan" berdasarkan Pasal 1365 KUHPerdata, ${ }^{23}$ sehingga perseroan sebagai badan hukum dapat dituntut pertanggungjawaban berdasarkan Pasal 1365 KUHPerdata. Pasal 1365 KUHPerdata yang berbunyi: “Tiap perbuatan melanggar hukum yang membawa kerugian kepada seorang lain, mewajibkan orang yang karena salahnya menerbitkan kerugian itu, mengganti kerugian tersebut"

Suatu perbuatan melawan hukum mengandung unsur-unsur sebagai berikut ${ }^{24}$, 1) adanya perbuatan, 2), perbuatan tersebut melawan hukum, 3), adanya kesalahan dari pihak pelaku,dan 4), adanya kerugian bagi korban, dan kelima adanya hubungan kausal antara perbuatan dengan kerugian.

Perbuatan si pelaku perbuatan melawan hukum dapat berupa berbuat sesuatu atau tidak berbuat sesuatu, di mana perbuatan dimaksud harus melawan hukum yang diartikan dalam arti luas yang meliputi ${ }^{25}$, pertama, perbuatan melanggar undang-undang yang berlaku. Kedua, melanggar hak orang lain yang dijamin oleh hukum. Ketiga, perbuatan yang bertentangan dengan kewajiban hukum si pelaku. Keempat, perbuatan yang bertentangan dengan kesusilaan, dan kelima, perbuatan yang bertentangan dengan sikap yang baik dalam masyarakat untuk memperhatikan kepentingan orang lain.

Unsur kesalahan merupakan unsur yang harus ada pada saat si pelaku perbuatan melawan hukum melakukan perbuatannya. Suatu perbuatan oleh hukum mengandung unsur kesalahan, sehingga dapat dimintakan tanggungjawab secara hukum jika memenuhi unsur kesengajaan, unsur kelalaian, dan unsur tidak ada alasan pembenar dan pemaaf, seperti keadaan overmacht, membela diri, tidak waras dan lain-lain. ${ }^{26}$

Unsur kerugian bagi korban juga merupakan syarat dalam dasar gugatan, di mana kerugian karena perbuatan melawan hukum disamping kerugian materiil, juga mengakui konsep kerugian immaterial, yang juga akan dinilai dengan uang. ${ }^{27}$

Mengenai unsur hubungan sebab akibat, adanya teori hubungan faktual dan teori penyebab kira-kira/teori relativitas/teori norma perlindungan. Hubungan

\footnotetext{
${ }^{23}$ Lihat Putusan perkara perdata No. 451/Pdt.G/2008/PN.JKT.BAR., hlm. 50

${ }^{24}$ Munir Fuady, Perbuatan Melawan Hukum ; Pendekatan Kontemporer, Penerbit PT.Citra Aditya Bakti, Bandung, 2005, hlm. 10., lihat juga Putusan perkara perdata No.451/Pdt.G/2008/PN.JKT.BAR., hlm. 53

${ }^{25}$ Ibid., hlm. 11., lihat juga Putusan perkara perdata No. 451/Pdt.G/2008/PN.JKT.BAR., hlm. 53-54

${ }^{26}$ Ibid., hlm. 12 lihat juga Putusan perkara perdata No. 451/Pdt.G/2008/PN.JKT.BAR.,hlm. 54

${ }^{27}$ Ibid., hlm. 13
} 
sebab akibat faktual merupakan hubungan sebab akibat senyatanya, di mana apa yang secara faktual telah terjadi itulah kenyataannya. Sedangkan hubungan sebab akibat menurut teori relativitas, agar seseorang dapat dimintakan tanggung jawab karena telah melakukan perbuatan melawan hukum, maka itu tidak cukup hanya menunjukkan adanya hubungan kausal antara perbuatan yang dilakukan dengan kerugian yang timbul, akan tetapi perlu juga ditunjukkan bahwa norma atau perbuatan yang dilanggar tersebut dibuat memang untuk melindungi kepentingan korban yang dilanggar. ${ }^{28}$

Dari fakta hukum di atas, pemberhentian Eddy Santoso Tjahja oleh Sung Samuel Ham Wing selaku Komisaris PT. JOBS DB dan PT. JOBS DB telah melanggar ketentuan-ketentuan di dalam UUPT maupun anggaran dasar perseroan, dan Sung Samuel Ham Wing selaku Komisaris PT. JOBS DB dan PT. JOBS DB telah melakukan perbuatan melawan hukum, sesuai dengan Pasal 1365 KUHPerdata.

\section{Akibat Hukum Atas Tindakan Komisaris Terhadap Pemberhentian Sementara Direksi yang Melawan Hukum}

Tindakan hukum Sung Samuel Ham Wing atas pemberhentian Eddy Santoso Tjahja selaku Komisaris PT. JOBS DB dan PT. JOBS DB tidak sah karena melanggar ketentuan peraturan perundang-undangan yang berlaku, sehingga secara yuridis, kedudukan Eddy Santoso Tjahja selaku Direktur PT. JOBS DB Indonesia harus dipulihkan hak-haknya yang seharusnya diterima sejak pemberhentian sementara.

Namun, tidak dapat dibayangkan apabila Eddy Santoso Tjahja telah dipulihkan hak-haknya oleh hukum dan kembali menjadi pengelola PT. JOBS DB dengan pihak PT. JOBS DB khususnya dengan Sung Samuel Ham Wing selaku Komisaris PT. JOBS DB. Setidaknya adanya hambatan psikologis yang akan terjadi, dalam pengelolaan perseroan selanjutnya diantara organ-organ perseroan di PT. JOBS DB. Hambatan psikologis hubungan internal perusahaan yang seharusnya bersinergi guna kemajuan perusahaan, dapat berkembang ketidakharmonisan antara direksi dan Komisaris PT. JOBS DB, sehingga menimbulkan hambatan pengurusan perseroan dalam rangka good corporate governance.

Sebaiknya ketentuan pemberhentian ini harus dijalankan dengan hati-hati, tidak tergesa-gesa. Komisaris baru dapat menyarankan pemberhentian direksi apabila 
segala upaya-upaya maksimal telah dilakukan oleh pihak Komisaris. Mengingat tugas utama dewan komisaris adalah melaksanakan pengawasan terhadap kebijaksanaan pengurusan perseroan yang dilakukan oleh direksi, dan memberikan nasihat kepada direksi dalam melaksanakan kepengurusan perusahaan.

\section{Penutup}

Sung Samuel Ham Wing selaku Komisaris PT. JOBS DB dan PT. JOBS DB telah melanggar ketentuan-ketentuan yang mengatur tata cara pemberhentian anggota direksi baik di dalam UUPT maupun anggaran dasar perseroan, dan telah melakukan perbuatan melawan hukum sesuai Pasal 1365 KUHPerdata.

Oleh karena mekanisme pemberhentian anggota direksi oleh dewan komisaris tidak sesuai dengan ketentuan UUPT dan anggaran dasar perseroan, maka pemberhentian dimaksud tidak sah dan harus dianggap tidak pernah ada. Sehingga segala hal yang berkaitan dengan akibat dari mekanisme pemberhentian yang melanggar ketentuan peraturan perundang-undangan yang berlaku, maka mempunyai akibat hukum yang tidak sah dan dianggap tidak pernah ada.

Pengelolaan perseroan yang baik, apabila organ-organ perseroan dalam menjalankan fungsinya selalu mengacu kepada UUPT, anggaran dasar perseroan dan peraturan perseroan. Hubungan antar institusi internal perusahaan harus selalu bersinergi, sesuai dengan maksud dan tujuan guna kemajuan perseroan. Perselisihan antar institusi internal perseroan, khususnya Direksi dan Komisaris dapat diminimalisir apabila perusahaan menerapkan prinsip-prinsip Good Corporate Governance (GCG).

\section{Daftar Pustaka}

Budiarto, Agus, Kedudukan Hukum dan Tanggung Jawab Pendiri Perseroan Terbatas, Penerbit Ghalia Indonesia, Jakarta 2002.

Chatamarrasjid, Menyikapi Tabir Perseroan, Kapita Selekta Hukum Perusahaan, Penerbit PT Citra Aditya Bakti, Bandung, 2000.

Arief T., Djohan, Aspek Hukum Perseroan Terbatas, Harvarindo, Jakarta, 2008.

Satrio Wicaksono, Frans, Tanggung Jawab Pemegang Saham, Direksi dan Komisaris Perseroan Terbatas (PT), Penerbit Visimedia, Cetakan 1, Jakarta, 2009.

Supramono, Gatot, Hukum Perseroan Terbatas Yang Baru, Djambatan, Jakarta, 2008. 
Widjaja, Gunawan, Seri Pemahaman Perseroan Terbatas, Risiko Hukum Sebagai Direksi, Komisaris \& Pemilik PT, Praninta Offset, Jakarta, 2008.

G Rai Widjaya, I., Hukum Perusahaan Perseroan Terbatas, Jakarta Kesaint Blanc, 2006.

Irwandi, Hukum Perusahaan Suatu Telaah Yuridis Normative, Mitra Karya, Jakarta, 2003.

Ginting, Jamin, Hukum Perseroan Terbatas (UU nomor 40 Tahun 2007), Penerbit PT. Citra Aditya Bakti, Bandung, 2007.

Wilamarta, Misahardi, Hak Pemegang Saham Minoritas Dalam Rangka Good Corporate Governance, Program Pascasarjana Fakultas Hukum Universitas Indonesia, Jakarta, Cetakan Pertama, 2002.

Fuady, Munir, Perseroan Terbatas Paradigma Baru, Citra Aditya Bakti, Bandung, 2003. , Perbuatan Melawan Hukum,Pendekatan Kontemporer, Penerbit PT. Citra Aditya Bakti, Bandung, 2005.

Yahya Harahap, M., Hukum Perseroan Terbatas, Penerbit Sinar Grafika, Cetakan Pertama, Jakarta, Juni 2009.

Khairandy, Ridwan, Perseroan Terbatas; Doktrin, Peraturan Perundang-undangan, dan Yurisprudensi, Penerbit Kreasi Total Media Yogyakarta, Cetakan Kedua (revisi), 2009

, Camelia Malik, Good Corporate Governance; Perkembangan, Pemilkiran dan Implementasinya di Indonesia Dalam Perspektif Hukum, Penerbit Kreasi Total Media, Yogyakarta, Cetakan Pertama, Agustus 2007

Agustina, Rosa, Perbuatan Melawan Hukum, Universitas Indonesia, Fakultas Hukum, Pascasarjana, 2003.

Sembiring, Sentosa, Hukum Perusahaan Tentang Perseroan Terbatas, Penerbit Nuansa Aulia, Bandung 2006.

Soerjono Soekanto, Pengantar Penelitian Hukum, Penerbit Universitas Indonesia Press, Jakarta, Cetakan Ketiga, 1986.

, Sri Mamuji, Penelitian Hukum Normatif(Suatu Tinjauan Singkat), Penerbit PT. Raja Grafindo Persada, Jakarta, Cetakan Keempat, 1994.

Silalahi, Udin, Badan Hukum dan Organisasi Perusahaan, Badan Penerbit Iblam, Jakarta, 2005.

Kitab Undang-Undang Hukum Perdata

Kitab Undang-undang Hukum Dagang

Undang-Undang Nomor 40 Tahun 2007 tentang Perseroan Terbatas

Peraturan Menteri No:M-01-HT.01-10 Tahun 2007, tentang Tata Cara Permohonan Pengesahan Badan Hukum dan Persetujuan Perubahan Anggaran Dasar, Penyampaian Pemberitahuan perubahan Anggaran Dasar dan perubahan Data Perseroan hanya Memberikan Kewenangan Kepada Notaris 
Peraturan Menteri No:M-02-HT.01-10 Tahun 2007 tentang Peraturan Menteri Hukum dan Hak Asasi manusia Republik Indonesia tentang Tata Cata Pengumuman Perseroan Terbatas dalam Tambahan Berita Negara Republik Indonesia

Putusan Pengadilan Negeri Jakarta Barat Perkara 451/Pdt.G/2008/PN.Jkt.Bar. 